\title{
Predatory evidence in the high-latitude cold-water gastropod Buccinanops deformis (King, 1832) from the Holocene littoral sand ridges, Argentina, SW Atlantic
}

\author{
Catalina Gómez-Espinosa, Ester Farinati, Salvador Aliotta
}

Catalina Gómez-Espinosa

c_gomez@ciencias.unam.mx

Universidad Autónoma de Guerrero, Escuela Superior de Ciencias de la Tierra, Ex Hacienda San Juan Bautista S/N, Taxco el Viejo, Guerrero, México, 40323.

\section{Ester Farinati}

Universidad Nacional del Sur, Departamento de Geología, San Juan 670, Bahía Blanca, Buenos Aires, Argentina, 8000.

\section{Salvador Aliotta}

Instituto Argentino de Oceanografía, Camino a La Carrindanga km 7.5, Bahía Blanca, Buenos Aires, Argentina, 8000.
BOL. SOC. GEOL. MEX. 2018

VOL. 70 NO. 2

P. $293-305$

http://dx.doi.org/10.18268/BSGM2018v70n2a2

\section{ABSTRACT}

In this study investigates the predatory activity on a Holocene gastropod from the Argentinean Malacological Province. Buccinanops deformis (King, 1832), endemic in the southern hemisphere, is a typical taxon of cold-waters and high latitudes. We observed direct evidence of durophagy as lethal and sublethal damage. Sublethal damage was studied using traces of repaired shell as an indicator of activity by durophagous predators. Three parameters were used to evaluate durophagous predation: frequency of predation, repair scar frequency and prey effectiveness. A predatory-prey interaction was identified between Danielethus crenulatus (A. Milne-Edwards, 1879) and B. deformis during the Holocene on the Argentinean littoral coast. The low value observed for shell repair frequency (0.06), the low frequency of predation (0.16), and the intermediate value for prey effectiveness $(0.37)$ may be interpreted because of a low but effective predatory activity.

Keywords: Predation, shell repair, high latitude, gastropod, Holocene, SW Atlantic.

\section{RESUMEN}

En este estudio se investiga la actividad depredadora sobre una especie de gasterópodo del Holoceno de la Provincia Malacológica Argentina. Buccinanops deformis (King, 1832) es una especie que habita en aguas frías en latitudes altas, endémica del Hemisferio Sur. Este estudio está basado en la evidencia directa de la durofagia tanto en daño letal como subletal. El daño subletal fue inferido utilizando la evidencia de los exoesqueletos reparadas como un proxy de este tipo de actividad. Se emplearon tres parámetros para la evaluación de la depredación durófaga: la frecuencia de depredación, la frecuencia de cicatrices reparadas y la efectividad de la presa. Se identificó la interacción depredador-presa entre el cangrejo Danielethus crenulatus (A. Milne-Edwards, 1879) y $\underline{B}$. deformis durante el Holoceno en las costas litorales argentinas. El bajo grado de la frecuencia de depredación (0.16) y reparación del exoesqueleto (0.06) y el valor medio de la efectividad de la presa (0.37) se interpretaron como resultado de una baja pero efectiva actividad depredadora.

Palabras clave: Depredación, reparación de exoesqueletos, latitudes altas, gasterópodos, Holoceno, SO del Atlántico. 


\section{Introduction}

The importance of predation as the main mechanism for metazoan evolution has been intensively studied since the 1980s (Skovsted et al., 2007) based on its role as a putative factor that contributes to natural selection (Vermeij, 1987; Kelley and Hansen, 1993; Jablonski and Sepkoski, 1996). Nevertheless, predation is one of the most difficult interspecific interactions to be estimated in the fossil record (Stuart and Greenstone, 1990), mainly because predators and prey are rarely found together (Molinaro et al., 2013). It is only possible to find direct evidence of predation on prey organisms possessing a biomineralized skeleton (Vermeij, 1987), whereas most predators either leave no trace or destroy the hard parts of their prey (Chattopadhyay and Baumiller, 2010).

Predation on organisms protected by a hard skeleton is defined as durophagy (Aronson, 2001).

It is considered that there are four molluscivory methods: the ingestion of the whole organism, insertion and extraction, boring followed by pre-ingestive breakage, and crushing (Harper and Skelton, 1993). The first two methods are unlikely to leave preservable evidence (Alexander and Dietl, 2003). The last two methods leave traces that may be considered as direct evidence and is commonly used as an indicator of durophagous predation (Kowalewsky, 2002).

In the fossil records, evidence shows that predation on gastropods was mainly by drilling, and there are several reports in the literature about that topic (see Kelley and Hansen, 2003).

The shell breakage caused by durophagy has been overlooked as it has been considered a misinterpretation because of (1) the effects of the shell's differential resistance towards taphonomic forces either before or after burial (Zuschin and Stanton, 2001; Zuschin et al., 2003; Mapes et al., 2010), (2) the destruction of shells by non-predatory action, and (3) shell scattering by currents or other mechanical agents (Vermeij et al., 1989).

Unsuccessful predation or sublethal damage is interpreted based on the degree of repair of the damaged shell. Recently this has emerged as a frequently used indicator for crushing-predation (Stafford and Leighton, 2011). Scars derived from repair processes are visible as disruptions of growth lines, visible as disruptions of surface ornaments, or as color patterns on the shell (Stafford $e t$ al., 2015).

Most publications regarding fossil records are focused on sublethal damage as they report gastropods' shell breakage (Vermeij, 1987; Alexander and Dietl, 2003; Skovsted et al., 2007; Lindström and Peel, 2010). A comprehensive review regarding fossil records of shell-breaking predation in gastropods was published by Alexander and Dietl (2003).

The damage inflicted on the external shell lip can be used to identify durophagous predation $(\mathrm{Oji}$ et al., 2003), although the lip may also be damaged by other carnivorous gastropods and crabs. This type of evidence has been formally described by Stafford et al. (2015) on an ichnofossil assigned to the Caedichnus ichnogenera.

Shell breakage caused by crabs is markedly different regarding severity, size, and position, and the breakage is distinguished by a peculiar pattern (Ogaya, 2004; Dietl et al., 2010).

Information describing repair frequencies is scarce for both fossil and recent mollusks located at Boreal to arctic latitudes (Alexander and Dietl, 2003). Moreover, except for one report (Chattopadhyay and Baumiller, 2010), prey effectiveness has not been estimated for fossilized repaired gastropods.

\section{Location}

Samples were collected at the Holocene sand shell ridges located at the inner region of the Bahia Blanca estuary, south of Buenos Aires Province, Argentina. Location: $38^{\circ} 45^{\prime} \mathrm{S}, 62^{\circ} 20^{\prime} \mathrm{W}$ (Figure $1)$.

The coastal region of this estuary is formed by a dense net of tidal channels separated by low altitude islands and sand shoals. Several geolo gical studies indicate that the Holocene marine 


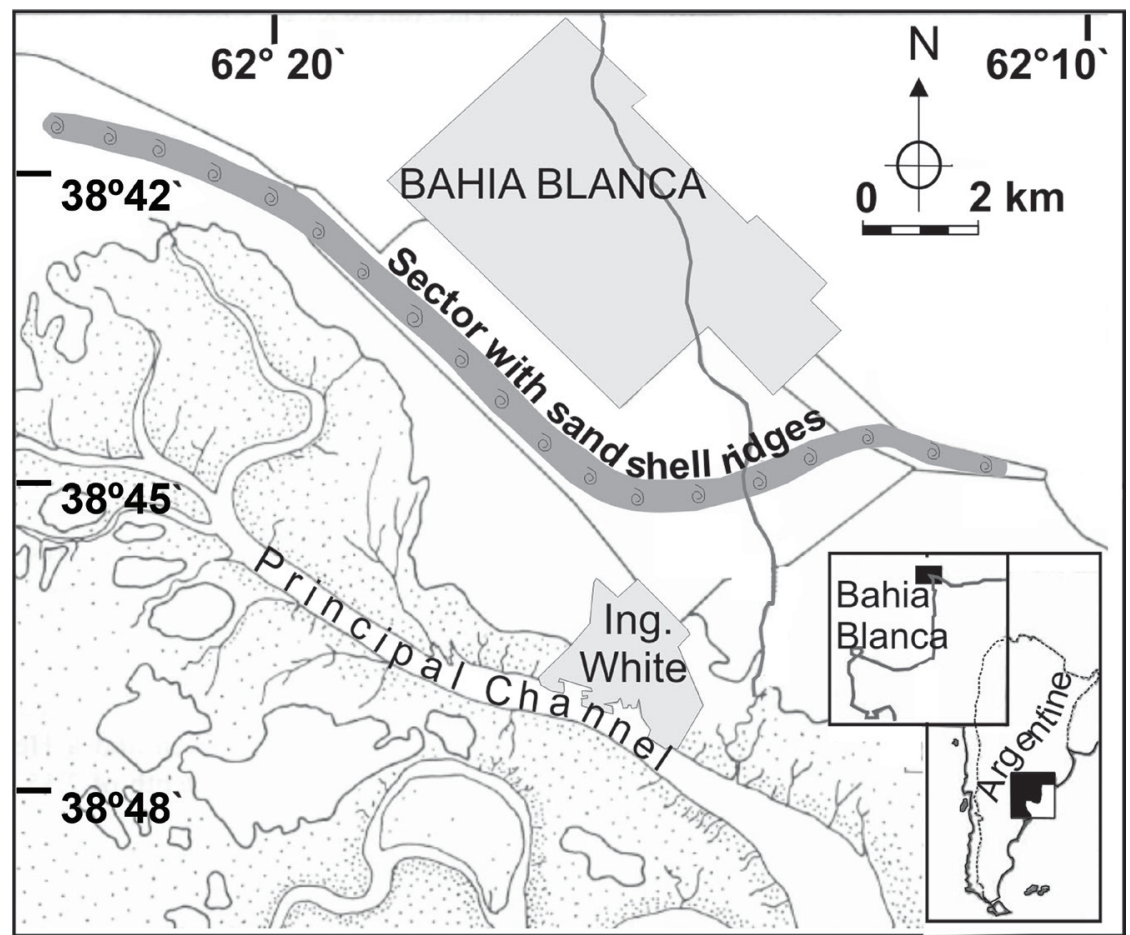

transgressive-regressive cycle has imprinted its particular features on the Bahía Blanca area (Aliotta et al., 2013).

The highest Holocene transgression produced a series of sand-shell ridges observed at heights ranging $8-10 \mathrm{~m}$ above mean sea level. These ridges are mainly found at the estuary's inner region and they are arranged in a narrow sub-parallel strip along the coastline (Farinati and Aliotta, 1987).

Sand-shell ridges are composed of size sands which range from medium to fine having a high percentage of whole shells and their fragments (approximately 30\%) as well as a smaller proportion of quartzite pebbles, calcrete, siltstone, and pumice (Aliotta and Farinati, 1990).

\section{Target taxa}

In this work we present documented evidence of durophagous predation in the Holocene gastropod Buccinanops deformis (King, 1832).
The Buccinanops genus (d'Orbigny, 1841) (Caenogastropoda, Nassariidae) has a geological record comprising the Upper Miocene to the Recent (Aguirre, 1993).

This species was selected because it is an abundant and conspicuous mollusk found in the sand-shell ridges of the Bahia Blanca estuary, and because it is a typical taxon of high latitudes endemic to the SW Atlantic Ocean, spanning from Espiritu Santo, Brazil to Golfo San Matías, Patagonia, Argentina (Nuñez and Narosky, 1997).

B. deformis possesses a smooth, wide, and thick shell, with a low and depressed spire and a subelliptical narrow opening. The shell has a well-developed siphonal canal. The inner lip is angled having a callus in its rear end whereas the outer lip is depressed. Shell height is of intermediate size (24 $-51 \mathrm{~mm}$ ) having 5 to $5^{1 / 2}$ whorls. The body whorl is almost five times larger than the spire (Figure 2A).

Members of Nassariidae family have been considered as carrion feeders, a proposal based on the 


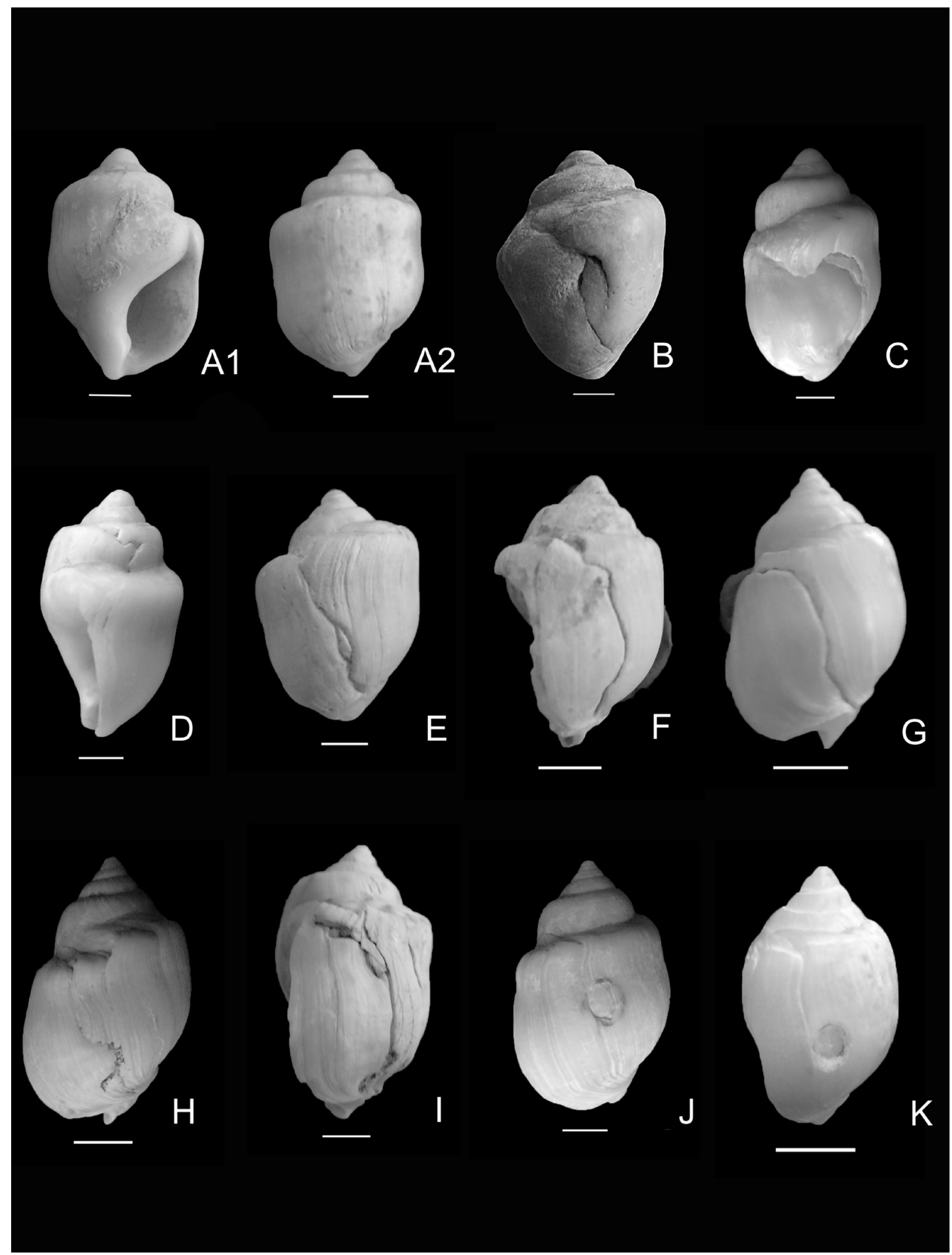

Figure 2 Buccinanops deformis (King, 1832) A1-A2. Non-preyed shell (PI-UNS 3183). B-K. Failed durophagous predation attempts. B-I. Side view showing Caedichnus sp. repaired shell. (PI-UNS 3184 - 3191); J-K. Side view showing punctures (PI-UNS 3192 - 3193 ). Scale bar $5 \mathrm{~mm}$. 
diet of the Nassarius genus (Harasewych, 1998). Nevertheless, the trophic aspects of this family are relatively unknown as data supporting this proposal are scarce and obtained from unpublished or undocumented sources (González et al., 2011). Only Buccinanops cochlidium (Dillwyn, 1817) has been reported as a carnivorous species (scavenger and predator) that fed on dead crabs and living bivalves (Averbuj et al., 2012). There are no references describing the diet consumed by $B$. deformis (King, 1832).

Regarding habitat, Buccinanops dwell in soft bottoms on intertidal or infralittoral zones in shallow waters (2 - $20 \mathrm{~m}$ deep) (Pastorino, 1993).

It is important to study an endemic genus of the Argentinean Malacological Province as it might represent cold water inhabitants, whereas most information describing predation on mollusks (whether living or fossil) is focused on species living in temperate and tropical waters (e.g., Carter, 1967; Vermeij, 1977a; Kowalewski et al., 1997; Kowalewski, 2002). Conversely, mollusks living in cool and cold waters have remained largely overlooked [exceptions are the studies conducted by Cadée (1999) and Bigatti et al. (2009)].

\section{Materials and methods}

Five bulk field samples were sieved through $4 \mathrm{~mm}$ mesh sieves. The samples were then washed and dried. The assemblages were almost entirely comprised by bivalves and gastropods. Other remains in this sample were chiton fragments, bryozoans, cirripedia, and decapods.

All shells were identified based on the taxonomy established by Aguirre (1993) and Farinati (1994). Mollusk assemblage includes 23 species of gastropod and 24 bivalve species (Aliotta et al., 2013). A selective sampling of specimens corresponding to the Buccinanops deformis gastropod (King, 1832) was carried out.

After cleaning the shells, the evidences of lethal and sublethal predation (repaired scars) were examined under a dissecting stereo-microscope.
Only those relatively intact specimens were selected for evaluating the effects of predation. Neither extensively abraded nor corroded shells were considered as these taphonomic features occlude the observation of scars on repaired shells. Three parameters were used to evaluate predation: frequency of predation, repair scar frequency, and prey effectiveness.

Frequency of predation was calculated by using the Lower Taxon Frequency method (LTF) (Kowalewski, 2002), where the number of specimens displaying evidences of lethal injury is divided by the total number of specimens in the sample (Equation 1).

$$
\mathrm{LTF}=\mathrm{Dk} / \mathrm{Nk} \quad \text { (Equation } 1)
$$

Where: $\mathrm{K}$ is the taxon target. $\mathrm{D}$ is the number of specimens displaying lethal predation evidences. $\mathrm{N}$ is the total number of specimens in the sample. The scar per shell method was used to calculate the repair scar frequency (Alexander and Dietl, 2003) where the total number of repaired scars is divided by the total number of individuals in the sample. This method was preferred over the scar per shell method because the latter underestimates the frequency of sublethal attacks within a population (Alexander and Dietl, 2003).

Prey effectiveness, a parameter to measure predator failure (Kowalewski, 2002), was quantified using Equation 2 and by considering the number of punctures and repaired shells.

$$
\mathrm{PE}=\mathrm{TF} / \mathrm{TT} \quad \text { (Equation 2) }
$$

Where PE is Prey effectiveness. TF is the number of specimens displaying punctures and repaired shells. TT is the number of specimens displaying evidence of predation.

Specimens described in this work are housed in the Paleontological Collection of The Universidad Nacional del Sur (PI-UNS), Bahía Blanca, Argentina.

A monospecific sample of the $B$. deformis gastropod that was sampled at $38^{\circ} 45^{\prime} \mathrm{S}, 62^{\circ} 20^{\prime} \mathrm{W}$ was dated 
with $\mathrm{C}^{14}$. Radiocarbon dating was performed at Laboratorio de Tritio y Radiocarbono (LATYR) from Universidad Nacional de la Plata (UNLP).

\section{Results}

The dating process for the shell indicates a ${ }^{14} \mathrm{C}$ age of $5690 \pm 70$ years BP.

A total amount of $540 \mathrm{~B}$. deformis shells were extracted from five bulk samples. Organisms from $23 \mathrm{~mm}$ to $35 \mathrm{~mm}$ of height are predominant in the samples.
From the 540 shells examined, 89 display predation evidence, 33 of the latter show evidence of sublethal damages (Figures 2B-K, 4A) whereas damage was lethal on 56 (Figures 3, 4B). Most of the observed predation evidence correlates with damage on the apertural lip and this kind of trace is identified as Caedichnus isp (Stafford et al., 2015) (Figures 2B-I, 3A-D, 4A-B). Very few shells exhibit punctures (Figures 2J-K, 3E-F). In agreement with the classification of Ekdale (1985), these types of evidence match the Praedichnia trace fossil.

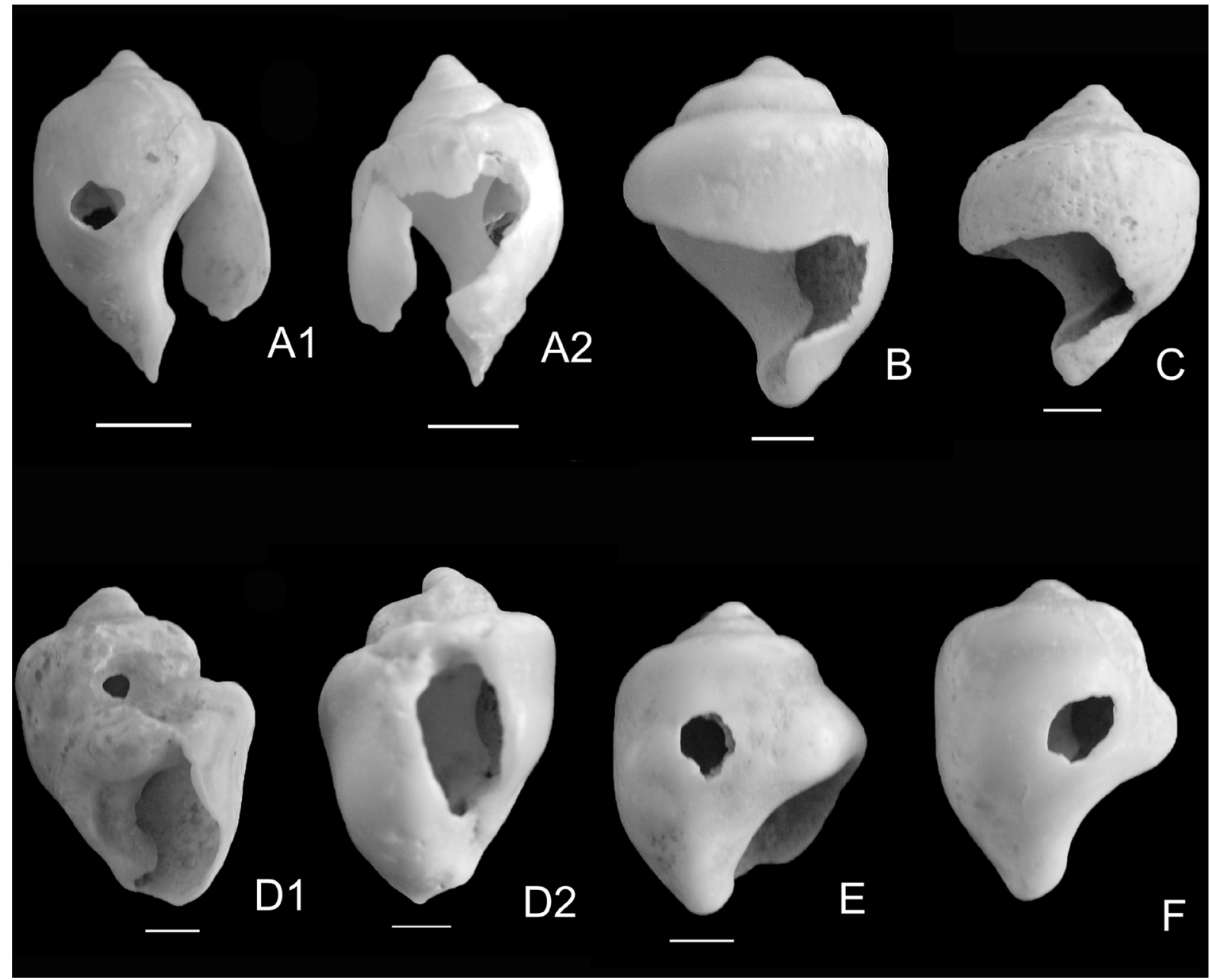

Figure 3 Lethal damage as a consequence of durophagous predation A-D. Caedichnus isp. A1. Side view showing puncture on the body whorl and a partial missing shell aperture. A2 shows continuation as an embayment fracture in the body whorl (PI-UNS 3194); B-C. Side view shows an embayment fracture on the body whorl (PI-UNS 3495 - 3196); D-F. Side view shows damage by puncture D. Shell displaying two punctures located at penultimate (D1) and body (D2) whorl. E-F Side view showing a puncture on the body whorl (PI-UNS 3198 - 3199). Scale bar $5 \mathrm{~mm}$. 


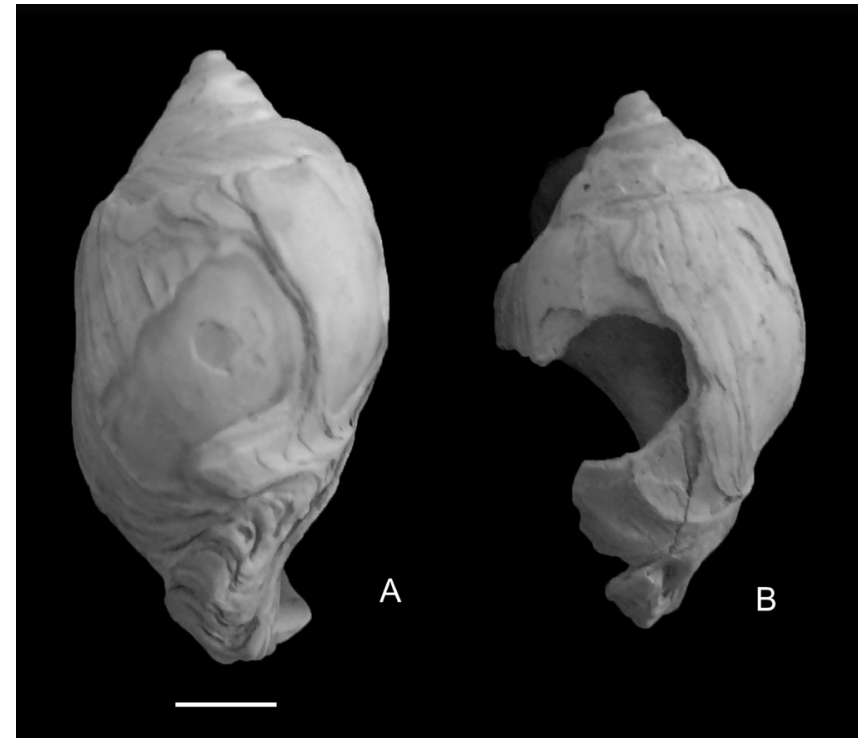

Figure 4 Caedichnus isp. shells exhibiting a large embayment fracture as consequence of crab predatory activity A. Side view showing deep breakage and repair damage on the body whorl (PI-UNS 3200); B. Side view showing a lethal injury observed as a deep shell breakage far back from the lip (PI-UNS 3201). Scale bar $5 \mathrm{~mm}$.

The frequency of predation (LTF) is $0.10(95 \%$ CI $\pm 1.17)$. The observed frequency of repaired scars is $0.06(95 \% \mathrm{CI} \pm 1.04)$ whereas prey effectiveness $\left(\mathrm{P}_{\mathrm{E}}\right)$ is $0.37(95 \% \mathrm{CI} \pm 2.58)$.

\subsection{LOGATION AND TYPE OF INJURIES}

Shell breakage by durophagy is the main evidence within the lethal damage category (Figures $3 \mathrm{~A}-\mathrm{C}$, 4B) and punctures are only observed on two shells (Figures 3E-F).

Repaired injuries on shells were the most abundant evidence within the sublethal damage category (Figures 2B-H, 4A) and punctures were observed on only two shells (Figure 2I-K). Some of the repaired scars show zigzag-breaking patterns (Figure 2D).

Frequently, the location of injuries is at the outer apertural lip region $(94.3 \%$ ) ranging from large embayment (Figures 2C, 3A-C, 4A-B) to irregular fracture (Figures 2B, 2D-F, 2H).

Repairing observed on the shells mostly occur along the whole-body whorl near the aperture $(96.9 \%)$
(Figures 2C, 2E-2I) and only one scar (equivalent to $3.1 \%$ ) is observed on the second whorl (Figure 2D). There is no evidence of removed apex or truncated apical end on the shells.

\section{Discussion}

It is recognized that predation is difficult to interpret in fossil record as some effects may mask predation intensity leading to the misinterpretation of the paleoecology assemblage (Harper et al., 1998). However, it is possible to distinguish predatory damage on the shell from abiotic damage (Alexander and Dietl, 2003). For instance, if a shell possesses a disrupted apertural margin, it is probably the consequence of durophagy rather than damage caused by water currents and, if the edges are smooth, this indicates transport or rework of the remains. Similarly, the cause of breakage can be distinguished in crushed shells based on the criterion of either a broken or unbroken shell aperture (Ogaya, 2004). Compaction may be important as well (e.g., Zuschin and Stanton, 2001; Klompmaker, 2009).

The $B$. deformis shells exhibit damage caused by predation, including breakage and puncture, which correlate with lethal and sublethal attacks. When shells exhibit sublethal damage caused by breakage, the individual's repair and growth continued with the subsequent modification of the shell's thickness. In the repaired area shells are thinner than the original and scars are not parallel to growth lines.

Apertural breakage is the most common evidence of predation on $B$. deformis as demonstrated by lethal and sublethal injuries. Predators' site-selectivity on the prey skeletons provides useful information on their interaction. In this case it is shown that the predator used a method consisting on insertion and molluscivory extraction. Thus, the predator must possess specialized physical structures to attack thick shells with a narrow aperture. 


\subsection{FREQUENGY OF PREDATION}

Predation intensity cannot be directly inferred and the only indirect approach to carry out its estimation is the predation frequency index. In this study a relatively low frequency of predation is observed, implying that almost none of the gastropods were attacked by durophagy. Although, if we consider that some of the shells were crushed by predators, this type of predation does not have a fossil record. When studying predation, the frequency of repaired scars may also be interpreted because of increased attacks (predation) or decreased successful attacks by predators (Kowalewski, 2002; Molinaro et al., 2013).

Nevertheless, a low predation frequency is consistent with the generally accepted idea that predation on gastropods is low in cool and temperate waters. It has been suggested that predation pressure is greater in tropics when compared to more temperate latitudes (Vermeij, 1983).

The low predation values are also comparable with those reported for tropical Paleozoic communities (Allmon et al., 1990; Gordillo and Archuby, 2014).

\subsection{REPAIR SHELL FREQUENGY AND PREY EFFEGTIVENESS}

The frequency of repaired scars is a commonly used indicator for durophagous predatory activities (Alexander and Dietl, 2003; Chattopadhyay and Baumiller, 2010; Klompmaker, 2011). The estimation of repaired shell frequency within an assemblage is a simple means to estimate the interaction between gastropods and their predators (Lindström and Peel, 2010), as it reflects the link between predator effectiveness and the prey's defenses.

Repaired shells cannot be used as measure of crushing intensity (Vermeij et al., 1980) because sublethal damage may be interpreted as failed predation or as predation by organisms that partially consume their prey. In this case, predation is interpreted as successful (Kowalewski, 2002).

Repaired shell frequency is low, implying either that predators were abundant and successful, or predators were scarce or ineffective (Schindel et al., 1982). Considering the variation of gastropod repair frequencies regarding latitude (the highest is observed in the tropics) (Vermeij et al., 1980), we suggest that predators were scarce.

Prey effectiveness indicates the shells' performance as anti-predatory mechanism (Vermeij et al., 1980). Vermeij (1983) considered that the incidence of unsuccessful predation provides a conservative measure of potential anti-predatory selection.

The obtained prey effectiveness value is low (0.37) compared to that obtained on field and laboratory studies carried out in tropical zones (e.g., Dietl, et al., 2010; Paul et al., 2013). This indicates the low potential of $B$. deformis against its predators. In this case, prey effectiveness may be a consequence of the predation frequency. If predation is low, gastropods are not forced to develop a complex antipredatory system.

Although it is not possible to confirm this proposal, we argue that a low shell repair frequency (0.06) and an intermediate value of prey effectiveness (0.37) on B. deformis is predominant at least at the Holocene sand shell ridges in Bahia Blanca. This may be interpreted as the consequence of a low but effective predatory activity. Alternative explanations for tropical environments were discussed extensively by Chattopadhyay and Baumiller (2007, 2010).

\subsection{GENOZOIC SHELL-BREAKING PREDATORS}

Vertebrate shell crushers include specialized teleost fishes, some coastal marine birds, sea otters, seal, and walruses. Among the invertebrates are palinurid lobsters, brachyuran crabs, pagurid crustaceans, stromatopods, and some octopuses (Alexander and Dietl, 2003).

Although the identification of a predator through traces is uncertain (Kowalewski, 2002), and in this case the causes of the shell's punctures are unknown, some of the observed injuries on the Buccinanops shells may be caused by crabs (see Vermeij, 1987). Brachyuran crabs have a broad diet but their predatory activity on gastropods is well known (Vermeij, 1977b). Members of the 
Platyxanthidae family are distinguished by marked differences in size between the left and right chelipeds. The larger one contains a crushing tooth as an adaptation to durophagy (Dietl and Vega, 2008; Schweitzer and Feldman, 2010). Crabs use at least three attack methods against gastropods: crushing, apertural breakage, and apex removal (Lawton and Hughes, 1985).

Predation on gastropod shells by crabs has been extensively described (Vermeij, 1977b; Zipser and Vermeij, 1978; Bertness and Cunningham, 1981; Lawton and Hughes, 1985; Ogaya, 2004; Dietl et al., 2010) and injury types and breakage patterns caused by them are well characterized and clearly distinguishable in fossil records.

Some of the damage inflicted on Buccinanops shells, either lethal (Figures 3A-C, 4A) or repaired (Figures 2C, 4B), exhibit apertural lip injuries observed as large embayed fracture of the body whorl. This type of damage has been observed as the consequence of predation by crabs (Dietl et al., 2010). The presence of complementary scars on opposite sides of the skeleton suggests that these traces were made by a scissor-like weapon, such as a crab's claw (Figures 3D-F) (Kowalewski et al., 1997).

Another fact supporting predation on Buccinanops by crabs is the presence of crab's chelipeds fragments of the Danielethus crenulatus (A. MilneEdwards, 1879) species (Decapoda, Brachyura, Platyxanthidae) along with gastropods in the same sample. The cheliped remains correlate with dactylus (Figure 5), that display sharp tips and molariform teeth typical of crushing crabs (Dietl and Vega, 2008; Schweitzer and Feldman, 2010). Nevertheless, portunids and xanthids crabs are currently considered as generalist and opportunistic feeders that occasionally eat hard-shelled preys, such as mollusks (Walker and Brett, 2002).

Buccinanops possess a particularly thick shell, maybe as an evolutionary adaptation against predation. In recent gastropods, shell thickness and defenses against predation by crabs was evaluated by Bertness and Cunningham (1981). They concluded that crabs of smaller size prefer thin shells, but larger crabs have no preference. Palmer (1985) also reported that small- and middle-size crabs preyed on thin shells, whereas the percentage of predation by middle-size crabs is low on thick shells, and the percentage is similar for predation by large-size crabs. A thick shell provides less gastropod vulnerability against small-size crabs, but predation is not completely excluded.

\section{Conclusions}

Apertural breakage is the most common predation trace on Buccinanops deformis either for lethal or sublethal injuries.

Most injuries, both lethal and sublethal, displayed by $B$. deformis shells are located at the body whorl and specifically at the external lip.

The low frequency (0.16) of durophagous predation is consistent with proposals suggesting low predation pressure at temperate latitudes.

The low value for shell repair frequency (0.06) along with the intermediate value for prey effectiveness (0.37) on B. deformis at the Holocene sand shell ridges in Bahia Blanca may be interpreted as the result of a low but effective predatory activity. The large embayment fractures, corresponding to Caedichnus isp., observed on the gastropod's body whorl may be attributed to predatory activity by crabs.

A Holocene predatory-prey interaction may be distinguished between the Danielethus crenulatus crab (predator) and the B. deformis gastropod (prey).

\section{Acknowledgements}

This research was supported by PGI 24/H099 and 24/H107 (Secretaría de Ciencia y Técnica, UNS) and PIP N 5538 and $N^{\circ} 00699$ (CONICET) projects. We express our sincere thanks to Greg Dietl and Gérard Breton for their comments, which greatly improved the quality of the paper. 


\section{References}

Aguirre, M.L., 1993, Type specimens of Quaternary marine gastropods from Argentina: Ameghiniana, 30, 23-38.

Alexander, R.R., Dietl, G.P., 2003, The fossil record of shell-breaking predation on marine bivalves and gastropods, in Kelley, P.H., Kowalewski, M., Hansen, T.A. (eds), Predator-Prey Interactions in the Fossil Record: New York, Kluwer Academic/ Plenum Press, 141-176.

Aliotta, S., Farinati, E., 1990, Stratigraphy of Holocene sand-shell ridges in the Bahia Blanca Estuary, Argentina: Marine Geology, 94(4), 353-360.

Aliotta, S., Ginsberg, S., Spagnuolo, J.O., Farinati, E., Giagante, D., Vecchi, L.G., 2013, Late Quaternary in a South Atlantic estuarine system: Stratigraphic and paleontologic indicators of coastal evolution: Journal of South American Earth Sciences, 45, 194-208.

Allmon, W.D., Nieh, J.C., Norris, R.D., 1990, Drilling and Peeling of Turritelline Gastropods since the Late Cretaceous: Palaeontology, 33, 595-611.

Aronson R.B., 2001, Durophagy in marine organisms, in Briggs, D.E.G, Crowther, P.R. (eds.), Palaeobiology II: Oxford, UK, Blackwell Science, 393-397.

Averbuj, A., Palomo, G., Brogger, M.I., Penchaszadeh, P.E., 2012, Diet and feeding of the nassariid Buccinanops cochlidium (Dillwyn, 1817) from Northern Patagonia, Argentina: Aquatic Biology, 17, 261-268.

Bertness, M., Cunningham, C., 1981, Crab shell-crushing predation and gastropod architectural defense: Journal of experimental marine biology and Ecology, 50, 213-230.

Bigatti, G., Sánchez, G.J.M., Miloslavich, P., Penchaszadeh, P.E., 2009, Feeding behavior of Adelomelon ancilla (Lightfoot, 1786): A predatory neogastropod (Gastropoda:
Volutidae) in Patagonian benthic communities: The Nautilus, 123, 159-165.

Cadée, G.C., 1999, Shell damage and shell repair in the Antarctic limpet Nacella concinna from King George Island: Journal of Sea Research, 41, 149-161.

Carter, R.M., 1967, On the biology and paleontology of some predators of bivalved Mollusca: Paleogeography, Paleoclimatology, Paleoecology, 4, 29-65.

Chattopadhyay, D., Baumiller, T.K., 2007, Drilling under threat: An experimental assessment of drilling behavior of Nucella lamellosa in the presence of a predator: Journal of Experimental Marine Biology and Ecology, 352, 257-266.

Chattopadhyay, D., Baumiller, T.K., 2010, Effect of durophagy on drilling predation: A case study of Cenozoic molluscs from North America: Historical Biology, 22(4), 367-379.

Dietl, G.P., Vega, FJ., 2008, Specialized shellbreaking crab claws in Cretaceous seas: Biological Letters, 4, 290-293.

Dietl, G.P., Durham, S.R., Kelley, P.H., 2010, Shell repair as a reliable indicator of bivalve predation by shell-wedging gastropods in the fossil record: Paleogeography, Paleoclimatology, Paleoecology, 296, 174-184.

Dillwyn, L.W., 1817, A descriptive catalogue of recent shells, arranged according to the Linnæan method; with particular attention to the synonymy: London, J. and A. Arch, 581-1092.

D’Orbigny, A., 1841, Voyages dans l'Amérique méridionale. 5, Part 3, Mollusques: Paris, France, P. Berdtan.

Ekdale, A.A., 1985, Paleoecology of the marine endobenthos: Palaeogeography, Palaeoecology, Palaeoclimatology, 50, 63-81.

Farinati, E., 1994, Micromoluscos (Gastropoda y Bivalvia) del Holoceno del Área de Bahía Blanca, Argentina: Ameghiniana, 31, 303-315. 
Farinati, E., Aliotta, S., 1987, Malacofauna holocena de un depósito litoral en las proximidades de Punta Alta, Provincia de Buenos Aires, Argentina (abstract), in Actas $4^{\text {th }}$ Congreso Latinoamericano de Paleontologia: Santa Cruz, Bolivia, 574-585.

González, S., Carranza, A., Scarabino, F., De Mello, G., Ligróne, A., 2011, Coexistence patterns of benthic gastropods: the genus Buccinanops (Nassariidae) the inner Uruguay continental shelf and the Río de la Plata estuary: Pan-American Journal of Aquatic Sciences, 6, 247-259.

Gordillo, S., Archuby, F.M., 2014, Live-Live and Live-Dead Interactions in Marine Death Assemblages: The Case of the Patagonian Clam Venus antiqua: Acta Paleontolologica Polonica, 59, 429-442.

Harasewych, M.G., 1998, Infraorder Neogastropoda, Family Nassariidae, in Beesley, L.P., Ross, G.J.B., Wells, A. (eds.), Mollusca: the Southern Synthesis: Melbourne, AU, Csiro Publishing, 819-845.

Harper, E.M., Skelton, P.W., 1993, The Mesozoic Marine Revolution and epifaunal bivalves: Scripta Geologica, Special Issue 2, 128-153.

Harper, E.M., Forsythe, G.T.W., Palmer, T., 1998, Taphonomy and the Mesozoic marine revolution: preservation state masks the importance of boring predators: Palaios, 13, 352-360.

Jablonski, D., Sepkoski, J.J. jr., 1996, Paleobiology, community ecology, and scales of ecological pattern: Ecology, 77, 1367-1378.

Kelley, P.H., Hansen, T.A., 1993, Evolution of the Naticid Gastropod Predator-Prey System: An Evaluation of the Hypothesis of Escalation: Palaios, 8, 358-375.

Kelley, P.H., Hansen, T.A., 2003, The fossil record of drilling predation on bivalves and gastropods, in Kelley, P.H., Kowalewski, M., Hansen, T.A. (eds.), Predator-Prey
Interactions in the Fossil Record: New York, Kluwer Academic/Plenum Press, 113-139.

King, P.P., 1832, Description of Cirrhipeda, Conchifera and Mollusca, in a collection formed by the officers of H.M.S. Adventure and Beagle employed between the years 1826 and 1830 in surveying the southern coasts of South America, including the Straits of Magalhaens and the coast of Tierra del Fuego ["assisted by W.J. Broderip"]: Zoological Journal, 5, 332-349.

Klompmaker, A.A., 2009, Taphonomy on drillhole predation intensities and paleoecology of Pliocene mollusks from Langenboom (Mill), The Netherlands: Palaios, 24, 772-779.

Klompmaker, A.A., 2011, Drilling and crushing predation on scaphopods from the Miocene of the Netherlands: Lethaia, 44, 429-439.

Kowalewski, M., 2002, The fossil record of predation: An overview of analytical methods, in Kowalewski, M., Kelley, P.H. (eds.), The fossil Record of Predation: Paleontological Society Papers, 8, 3-42.

Kowalewski, M., Flessa, K.W., Marcot, J.D., 1997, Predatory scars in the shells of a recent lingulid brachiopod: Paleontological and ecological implications: Acta Palaeontologica Polonica, 42, 497-532.

Lawton, P., Huges, R.N., 1985, Foraging behaviour of the crab Cancer pagurus feeding on the gastropods Nucella lapillus and Littorina littorea: comparisons with optimal foraging theory: Marine Ecology Progress Series, 27, 143-154.

Lindström, A., Peel, J.S., 2010, Shell repair and shell form in Jurassic pleurotomarioid gastropods from England: Bulletin of Geosciences, 8, 541-550.

Mapes, R.H., Landman, N.H., Cochran, K., Goiran, C., Richer, B., Renfro, A., 2010, Early taphonomy and significance of naturally submerged Nautilus shells from the New Caledonia Region: Palaios, 25, 597-610. 
Molinaro, D.J., Stafford, E.S., Collins, B.M.J., Barclay, K., Tyler, C.L., Leighton, L.R., 2013, Peeling out predation intensity: can repair frequency be a useful proxy towards understanding predation? (Abstract), in Geological Society of America Abstracts with Programs: Denver, USA, 45, 756.

Nuñez, G., Narosky, T., 1997, Cien caracoles argentinos, Buenos Aires, Editorial Albatros, $158 \mathrm{p}$.

Ogaya, C., 2004, Presence or absence of the shell aperture: a criterion to identify shell breakage induced by durophagy in Umbonium (Mollusca: Gastropoda: Trochidae): Paleontological Research, 8, 311-324.

Oji, T., Ogaya, C., Sato, T., 2003, Increase of shellcrushing predation recorded in fossil shell fragmentation: Paleobiology, 29, 520-526.

Palmer, A.R., 1985, Adaptive value of shell variation in Thais lamellosa: effects of thick shells on vulnerability to and preference by crabs: Veliger, 27, 349-356.

Paul, G., Das, A., Bardhan, S., Mondal, S., 2013, Predation on Recent Turritelline Gastropods from the Indian Subcontinent and Comparison with a Revised Global Database: Malacologia, 56, 193-213.

Pastorino, G., 1993, The taxonomic status of Buccinanops d'Orbigny, 1841 (Gastropoda: Nassariidae): The Veliger, 36, 160-165.

Schindel, D.E., Vermeij, D.E., Zipser, E., 1982, Frequency of repaired shell fractures among the Pennsylvanian gastropods of NorthCentral Texas: Journal of Paleontology, 56, 729-740.

Schweitzer, C.E., Feldman, R.M., 2010, The Decapoda (Crustacea) as predators on Mollusca trough geologic time: Palaios, 25, 167-182.

Skovsted, G.B., Brock, G.A., Lindström, A., Peel, S.J., Paterson, J.R., Fuller, R.K., 2007, Early Cambrian record of failed durophagy and shell repair in an epibenthic mollusc: Biology Letters, 3, 314-317.
Stafford, E.S., Leighton, L.R., 2011, Vermeij crushing analysis: A new old technique for estimating crushing predation in gastropod assemblages: Palaeogeography, Palaeoclimatology, Palaeoecology, 305, 123-137.

Stafford, E.S., Dietl, G.P., Gingras, M.P., Leighton, L.R., 2015, Caedichnus, a New Ichnogenus Representing Predatory Attack on the Gastropod Shell Aperture: Ichnos, 22, 87-102.

Stuart, M.K., Greenstone, M.H., 1990, Beyond ELISA: a rapid, sensitive, specific immunodot assay for identification of predator stomach contents: Annals of the Entomological Society of America, 83, 1101-1107.

Vermeij, G.J., 1977a, The Mesozoic Marine Revolution: Evidence from Snails, Predators and Grazers: Paleobiology, 3, 245-258.

Vermeij, G.J., 1977b, Patterns in crab claw size: the geography of crushing: Systematic Zoology, 26, 138-151.

Vermeij, G.J., 1983, Traces and trends of predation, with special reference to bivalved animals: Paleontology, 26, 455-465.

Vermeij, G.J., 1987, Evolution and Escalation: An ecological history of life: New Jersey, USA, Princeton University Press, $527 \mathrm{p}$.

Vermeij, G.J., Zipser, E., Dudley, E.G., 1980, Predation in time and space: peeling and drilling in terebrid gastropods: Paleobiology, 6, 352-364.

Vermeij, G.J., Zipser, E., Dudley, E.C., 1989, Successful and unsuccessful drilling predation in recent pelecypods: Veliger, 32, 266-273.

Walker, S.E., Brett, C.E., 2002, Post-Paleozoic patterns in marine predation: Was there a Mesozoic and Cenozoic marine predatory revolution?, in Kowalewski, M., Kelley, P.H. (eds.), The Fossil Record of Predation: The Paleontological Society Papers, 8, 119-194.

Zuschin, M., Stanton, R.J., 2001, Experimental Measurement of Shell Strength and its Taphonomic Interpretation: Palaios, 16, 161-170. 
Zuschin, M., Stachowitsch, M., Stanton, R.J., 2003, Patterns and processes of shell fragmentation in modern and ancient marine environments: Earth Science Reviews, 63, 33-82. 